UDK $577.1: 61$

ISSN 1452-8258

\title{
HDL CHOLESTEROL IS ASSOCIATED WITH PBMC EXPRESSION OF GENES INVOLVED IN HDL METABOLISM AND ATHEROGENESIS
}

\author{
POVEZANOST HDL HOLESTEROLA SA PBMC EKSPRESIJOM GENA \\ KOJI SU UKLJUČENI U HDL METABOLIZAM I ATEROGENEZU
}

\author{
Liudmila V. Dergunova1, Elena V. Nosova1, Veronika G. Dmitrieva1,2, Alexandra V. Rozhkova1, \\ Ekaterina V. Bazaeva², Svetlana A. Limborska1, Alexander D. Dergunov² \\ ${ }^{1}$ Laboratory of Functional Genomics, Institute of Molecular Genetics \\ of the Russian Academy of Sciences, Moscow, Russia \\ ${ }^{2}$ Laboratory of Structural Fundamentals of Lipoprotein Metabolism, \\ National Research Centre for Preventive Medicine, Moscow, Russia
}

\section{Summary}

Background: To reveal the association of plasma level of high density lipoprotein cholesterol (HDL-C) level with the transcript level of annotated genes in peripheral blood mononuclear cells (PBMC) and involved in HDL metabolism and atherogenesis at the absence of morphologically evident coronary stenosis.

Methods: Transcript levels of 63 genes in PBMC from 38 male patients $40-60$ years without coronary atherosclerosis with widely varied HDL-C level were measured. The protein interactions were analyzed with STRING database.

Results: Among $22 \mathrm{HDL}$-related genes, the transcript levels for 10 genes (ABCA1, BMP1, CUBN, HDLBP, LCAT, LDLR, $P R K A C B, P R K A C G, S C A R B 1$ and ZDHHC8) negatively correlated with HDL-C, while positively for APOA1 gene. Among 41 atherosclerosis-prone genes, the transcript levels for 11 genes (CSF1R, CSF2RB, IL18R1, ITGAM, ITGB3, PRKCQ, SREBF1, TLR5, TLR8, TNFRSF1A and TNFRSF1B) negatively correlated with HDL-C only, not with LDL-C and plasma TG. The protein products efficiently interacted within each cluster while only two intersection nodes existed between clusters.

Conclusions: Coordinate regulation of cholesterol influx and efflux in PBMC in atherosclerosis-free subjects with widely varied HDL-C level is suggested. The decreased synthesis and transport of cholesteryl ester to the liver may

Address for correspondence:

Liudmila V. Dergunova, PhD.

2, Kurchatov square, 123182 Moscow, Russia

Phone: +7 (499) 196-1858

e-mail: Ivdergunova@mail.ru

\section{Kratak sadržaj}

Uvod: Cilj rada je otkrivanje povezanosti nivoa lipoproteinskog holesterola visoke gustine u plazmi (HDL-C) sa nivoom transkripta anotiranih gena u mononuklearnim ćelijama periferne krvi (PBMC), a koji su uključeni u HDL metabolizam i aterogenezu u odsustvu morfološki evidentne koronarne stenoze.

Metode: Izmereni su nivoi transkripta 63 gena u PBMC kod 38 pacijenata muškog pola starosti između 40 i 60 godina bez koronarne ateroskleroze sa značajno raznovrsnim nivoom HDL-C. Interakcije proteina su analizirane pomoću STRING baze podataka.

Rezultati: Među 22 gena povezana sa HDL, nivoi transkripta za 10 gena (ABCA1, BMP1, CUBN, HDLBP, LCAT, LDLR, PRKACB, PRKACG, SCARB 1 i ZDHHC8) su bili u negativnoj korelaciji sa HDL-C, dok je korelacija pozitivna za gen APOA1. Od 41 gena koji su skloni aterosklerozi, nivoi transkripta za 11 gena (CSF1R, CSF2RB, IL18R1, ITGAM, ITGB3, PRKCK, SREBF1, TLR5, TLR8, TNFRSF1A TNFRSF1B) su u negativnoj korelaciji samo sa HDL-C, ali ne sa LL-C-C, i TG u plazmi. Proteinski proizvodi efikasno su delovali u svakom klasteru, dok su između klastera postojala samo dva čvora preseka.

Zaključak: Predlaže se koordinisana regulacija priliva i odliva holesterola u PBMC kod subjekata bez ateroskleroze sa širokim opsegom vrednosti nivoa HDL-C. Smanjena sinteza

List of abbreviations: Chol, cholesterol; FDR, false discovery rate; GWAS, genome wide association study; HDL-C, highdensity lipoprotein cholesterol; LDL-C, low-density lipoprotein cholesterol; PBMC, peripheral blood mononuclear cells; GPCR, quantitative polymerase chain reaction; $R C T$, reverse cholesterol transport; RT-PCR, real-time polymerase chain reaction; TG, triglyceride. 
contribute to hyperalphalipoproteinemia. HDL-C increase is associated with the decrease of expression of innate immunity and inflammation genes. Visualization of 22 responder genes is suggested to be useful in the validation of HDL functionality and atherogenesis even at the absence of morphologically evident coronary stenosis

Keywords: atherogenesis, gene expression, HDL functionality, HDL and atherogenesis-prone genes, human PBMC

\section{Introduction}

Coronary heart disease is one of the major mortality causes around the globe (1). The major underlying effects are the disturbances of lipid metabolism and atherogenesis with the contribution of immunological and metabolic processes (2). For a long time, the primary goal in the treatment of atherogenic dyslipidemia was to decrease the low-density lipoprotein cholesterol (LDL-C) and to increase high-density lipoprotein cholesterol (HDL-C). The proatherogenic role of $\mathrm{LDL}$ was opposed to the atheroprotective role of $\mathrm{HDL}$ as cholesterol acceptors (3), thus forming the reverse cholesterol transport (RCT) from lipid-loaded macrophages to the liver (4). Also, HDL possesses many pleiotropic atheroprotective properties such as endothelium protection, antioxidant, anti-inflammatory, anti-apoptotic and anti-thrombotic effects $(5,6)$. However, some genetic and clinical data challenged the atheroprotective significance of circulating HDL. The functional mutations of ABCA1 gene with low $\mathrm{HDL}-\mathrm{C}$ levels did not increase the risk of coronary heart disease (7), while the increase of HDL-C level did not decrease the risk (8) and even increased it in some circumstances. GWAS studies revealed many single nucleotide polymorphisms associated with HDL content without any definitive conclusions on the association of HDL-C with coronary heart disease (9). The loss of the atheroprotective properties of HDL may be related to their functional properties, not with their concentration (10). The appearance of dysfunctional HDL may be caused by the loss of anti-inflammatory and antioxidant proteins with the concomitant appearance of pro-inflammatory proteins in HDL particles $(11,12)$. Thus, the epidemiology, genetics, clinical and experimental data accumulated up to date do not unequivocally relate HDL-C as an anti-atherogenic factor.

To reveal the HDL role on the transcriptome level, we selected some genes with the expression in peripheral blood mononuclear cells (PBMC) (13). Among them, 22 genes involved in HDL metabolism (HDL cluster) were chosen. In addition, 41 genes involved in inflammation and other atherogenesisprone processes (atherogene cluster) were included based on the GWAS data on differentially expressed genes in PBMC in atherosclerosis versus control and RT-PCR data (13). In a pilot study with a small group of patients without coronary atherosclerosis, we com- i transport holesterol estra do jetre može doprineti hiperalfalipoproteinemiji. Povećanje HDL-C povezano je sa smanjenjem ekspresije gena $u$ vezi sa urođenim imunitetom i upalnim procesima. Vizualizacija ovih 22 gena može biti korisna u validaciji HDL funkcionalnosti i aterogeneze, čak i u odsustvu morfološki vidljive koronarne stenoze.

Ključne reči: aterogeneza, ekspresija gena, HDL funkcionalnost, HDL i geni skloni aterogenezi, humani PBMC

pared the expression of HDL cluster genes in PBMC, $\mathrm{HDL}$ charge heterogeneity and cholesterol acceptor capacity of patient HDL in cholesterol efflux assay (14). The expression of several HDL-related genes, cholesterol efflux efficiency and concentration of pre $\beta$-HDL significantly differed between hypo- and hyperalphalipoproteinemics (14). However, the joint consideration of the expression of atheroprotective and pro-atherogenic genes in relation to HDL-C level in the same group of patients is still lacking.

The aim of the present study is to reveal the association of plasma level of high-density lipoprotein cholesterol level with the transcript level of selected genes in peripheral blood mononuclear cells (PBMC) and involved in $\mathrm{HDL}$ metabolism and atherogenesis at the absence of morphologically evident coronary stenosis.

\section{Materials and Methods}

\section{Patients and laboratory tests}

Thirty-eight white Caucasian male patients at the age between 40 and 60 from the Moscow region were enrolled in the study (Table I). The inclusion criteria were the absence of coronary deficiency and stenosis of coronary/carotid arteries verified by coronary angiography and ultrasonography, respectively, the absence of hypertension and diabetes, non-alcoholics, the absence of therapy by corticosteroids and

Table I Characteristics of the study group. White Caucasian male patients from the Moscow region were enrolled in the study. Parameter variations between minimal and maximal values are given also.

\begin{tabular}{|l|c|c|}
\hline & $\begin{array}{c}\text { Mean } \pm \text { SD } \\
(\mathrm{n}=38)\end{array}$ & Variation \\
\hline Age, years & $49.1 \pm 5.7$ & $40.0-60.0$ \\
\hline Body mass index, $\mathrm{kg} / \mathrm{m}^{2}$ & $28.5 \pm 3.1$ & $21.0-31.0$ \\
\hline $\mathrm{Chol}, \mathrm{mmol} / \mathrm{L}$ & $5.19 \pm 1.27$ & $2.40-7.80$ \\
\hline $\mathrm{HDL}-\mathrm{C}, \mathrm{mmol} / \mathrm{L}$ & $1.19 \pm 0.35$ & $0.59-2.24$ \\
\hline $\mathrm{LDL}-\mathrm{C}, \mathrm{mmol} / \mathrm{L}$ & $3.31 \pm 1.05$ & $1.14-5.98$ \\
\hline TG, $\mathrm{mmol} / \mathrm{L}$ & $1.52 \pm 0.71$ & $0.59-3.42$ \\
\hline
\end{tabular}


hypolipidemic agents for at least 3 months. The informed consent was obtained from each patient, and the local ethical committee approved protocol corresponding to the Helsinki declaration from 1975. Plasma lipid levels (Table $I$ ) were measured by enzyme methods with Architect c8000 (Abbott, USA).

Gene expression analysis by quantitative real-time $P C R$

Ficoll-Hypaque $(1.077 \mathrm{~g} / \mathrm{mL})$ density gradient centrifugation (Sigma, USA) was performed to isolate peripheral blood mononuclear cells. Total RNA was isolated with TRI Reagent (Molecular Research Center, USA) and traces of DNA were removed by DNase I in the presence of RNase inhibitor according to the manufacturer's protocol (ThermoFisher Scientific, USA). RNA samples were kept at $-70{ }^{\circ} \mathrm{C}$. RNA concentration and quality (RQI > 9) were measured with the Experion electrophoresis system (BioRad, USA). cDNA was synthesized with RevertAid First Strand cDNA Synthesis Kit (ThermoFisher Scientific, USA) and cDNA samples were kept at $-20{ }^{\circ} \mathrm{C}$.

HDL cluster included the following genes: Albumin (ALB); Alpha-2-macroglobulin (A2M); Amnion associated transmembrane protein $(A M N)$; Apolipoprotein A1 (APOA1); Apolipoprotein C2 (APOC2); Apolipoprotein E (APOE); ATP binding cassette subfamily A member 1 ( $A B C A 1)$; ATP binding cassette subfamily $\mathrm{G}$ member 1 (ABCG 1); Bone morphogenetic protein 1 (BMP1); Cholesteryl ester transfer protein (CETP); Cubilin (CUBN); High density lipoprotein binding protein (HDLBP); Lecithin-cholesterol acyltransferase (LCAT); Lipase $C$, hepatic type $(L I P C)$; Lipoprotein lipase (LPL); Low density lipoprotein receptor $(L D L R)$; Phospholipid transfer protein $(P L T P)$; Protein kinase cAMP-activated catalytic subunit alpha (PRKACA); Protein kinase CAMP-activated catalytic subunit beta (PRKACB); Protein kinase cAMP-activated catalytic subunit gamma (PRKACG); Scavenger receptor class $\mathrm{B}$ member 1 (SCARB 1); Zinc finger DHHC-type containing 8 (ZDHHC8).

Atherogene cluster included the following genes: Asialoglycoprotein receptor 2 (ASGR2); CD14 molecule (CD14); CD36 molecule (CD36); Coagulation factor $V(F 5)$; Colony stimulating factor 1 receptor (CSF1R); Colony stimulating factor 2 receptor beta common subunit (CSF2RB); C-X-C motif chemokine ligand 5 (CXCL5); Cytochrome b-245 alpha chain (CYBA); Integrin subunit alpha $2 b$ (ITGA2B); Integrin subunit alpha M (ITGAM); Integrin subunit beta 3 (ITGB3); Intercellular adhesion molecule 1 (ICAM 1); Interleukin 1 beta (IL 1B); Interleukin 1 receptor type 1 (IL 1R 1); Interleukin 18 (IL18); Interleukin 18 receptor 1 (IL18R1); Interleukin 18 receptor accessory protein (IL18RAP); Junctional adhesion molecule 3 (JAM3); Lymphotoxin alpha (LTA); Matrix metallopeptidase 9 (MMP9); Microsomal glutathione S-transferase 1 (MGST1); NPC intracellular cholesterol transporter 1 (NPC 1); NPC intracellular cholesterol transporter 2 (NPC2); Nuclear receptor subfamily 1 group $\mathrm{H}$ member 2 (NR1H2); Nuclear receptor subfamily 1 group $\mathrm{H}$ member 3 (NR1H3); Oxidized low density lipoprotein receptor 1 (OLR1); Phosphatidylcholine transfer protein (PCTP); Phospholipase A2 group VII (PLA2G7); Protein kinase $\mathrm{C}$ theta (PRKCQ); S100 calcium binding protein A12 (S100A12); S100 calcium binding protein A8 (S100A8); S100 calcium binding protein A9 (S100A9); Secretory leukocyte peptidase inhibitor (SLPI); Solute carrier family 7 member 11 (SLC7A11); Sterol regulatory element binding transcription factor 1 (SREBF 1); Superoxide dismutase 2 (SOD2); TNF receptor superfamily member $1 \mathrm{~A}$ (TNFRSF1A); TNF receptor superfamily member 1B (TNFRSF1B); Toll like receptor 5 (TLR5); Toll like receptor 8 (TLR8); Vascular endothelial growth factor A (VEGFA).

Housekeeping genes included Glyceraldehyde3-phosphate dehydrogenase (GAPDH); Lactate dehydrogenase $A(L D H A)$ and Ribosomal protein $L 3$ (RPL3) genes.

Gene-specific primers were designed using OLIGO Primer Analysis Software 6.31 (Molecular Biology Insights, USA). Primer structures and coordinates according to mRNA for forty-one genes involved in atherogenesis and for two HDL-related LDLR and LIPC genes are given in Table II. We described earlier the primers for three housekeeping GAPDH, RPL3 and LDHA genes and for twenty HDLrelated genes ABCA1, ABCG1, SCARB1, CETP, PRKACA， PRKACB， PRKACG， LCAT， HDLBP， ZDHHC8, A2M, AMN, ALB, CUBN, BMP1, LPL, PLTP, APOA1, APOE and APOC2 (14). Analysis of primer specificity and protocol of real-time quantitative polymerase chain reaction ( $(\mathrm{PPCR})$ were performed as previously described (14).

Analysis of interaction between protein products of genes belonging to two clusters

The analysis was performed with STRING database (15) with six kmeans clusters. The $p$-value for protein-protein interaction (PPI) enrichment is an indicator of interaction efficiency. The number of nodes and the number of edges are network characteristics.

\section{Statistical analysis}

Statistical analysis was performed using STATISTICA 8.0 data analysis software system (StatSoft, Inc. (2008)). We applied the Shapiro-Wilks W test to check the normality and nonnormally distributed data were log-transformed to approach a Gaussian distribution. The data are expressed as mean \pm SD. The 
Table II The primers used for a quantitative real-time polymerase chain reaction.

\begin{tabular}{|c|c|c|c|c|}
\hline Primer & GeneBank & 5'- 3' nucleotide sequence & location & efficiency \\
\hline \multicolumn{5}{|c|}{ Genes involved in atherogenesis } \\
\hline ASGR2 (F) & NM_001181.4 & GGAGAAACAGCAGCAGGACC & $663-682$ & \multirow{2}{*}{1.65} \\
\hline ASGR2 (R) & & GAGTGAGAGAACCAGTAGCAGC & $827-848$ & \\
\hline CD14 (F) & NM_000591.3 & CAAGTGTGAAGCCTGGAAGC & $277-296$ & \multirow{2}{*}{1.80} \\
\hline CD14 (R) & & ACAAGGTTCTGGCGTGGTC & $436-454$ & \\
\hline CD36 (F) & NM_000072.3 & CCTTTGCCTCTCCAGTTGAA & $1310-1329$ & \multirow{2}{*}{1.99} \\
\hline CD36 (R) & & GTACACAGGTCTCCCTTCTTTG & $1413-1434$ & \\
\hline CSF1R $(F)$ & NM_005211.3 & GGTGGCAGGAAGGTGATGT & $836-854$ & \multirow{2}{*}{1.71} \\
\hline CSF1R (R) & & GGTGTTGTTGTGTTGGAGGA & $999-1018$ & \\
\hline CSF2RB (F) & NM_000395.2 & АТССТССТСТССААСАССТСС & $776-796$ & \multirow{2}{*}{1.80} \\
\hline CSF2RB (R) & & АССТССТТССТСАССТСССА & $1001-1020$ & \\
\hline CXCL5 (F) & NM_002994.4 & GCTGTTGGTGCTGCTGCT & $208-225$ & \multirow{2}{*}{1.81} \\
\hline CXCL5 (R) & & CCGTTCTTCAGGGAGGCTAC & $389-408$ & \\
\hline CYBA (F) & NM_000101.3 & TTGTGTGCCTGCTGGAGTA & $214-232$ & \multirow{2}{*}{1.70} \\
\hline CYBA (R) & & AGTAGGTAGATGCCGCTCG & $421-439$ & \\
\hline$F 5(F)$ & NM_000130.4 & CTGGCTGGTGGCTCCTAA & $5781-5798$ & \multirow{2}{*}{1.57} \\
\hline$F 5(R)$ & & ATCTTGCTAATCTGGGCTCC & $5941-5960$ & \\
\hline JAM3 (F) & NM_032801.4 & TTCCAGAGCCAATCCCAGA & $708-726$ & \multirow{2}{*}{1.90} \\
\hline$J A M 3(R)$ & & TCCGCCAATGTTCAGGTC & $874-891$ & \\
\hline ICAM1 (F) & NM_000201.2 & GTGACCGTGAATGTGCTCTCC & $1727-1747$ & \multirow{2}{*}{1.83} \\
\hline ICAM1 (R) & & GAGGCGTGGCTTGTGTGTT & 1895-1913 & \\
\hline$I L 1 B(F)$ & NM_000576.2 & TGTCCTGCGTGTTGAAAGATGA & $641-662$ & \multirow{2}{*}{1.84} \\
\hline$I L 1 B(R)$ & & CTGCTTGAGAGGTGCTGATGTA & $796-817$ & \\
\hline IL1R1 (F) & NM_000877.3 & TGCTTACTGGAAGTGGAATG & $1099-1118$ & \multirow{2}{*}{1.76} \\
\hline IL1R1 (R) & & TGCTGCATCTATACCATGTG & $1278-1297$ & \\
\hline IL18 (F) & NM_001562.3 & GACCAAGGAAATCGGCCT & $395-412$ & \multirow{2}{*}{1.81} \\
\hline$I L 18(R)$ & & CACAGAGATAGTTACAGCCATACC & $503-526$ & \\
\hline IL18RAP (F) & NM_003853.3 & ACAACCCAGTCCGTCCAAC & $1524-1542$ & \multirow{2}{*}{1.86} \\
\hline IL18RAP (R) & & ACATCAGGAAATAGGCTCAGG & $1790-1810$ & \\
\hline IL 18R1 (F) & NM_003855.3 & CGATAAAGAAGAACGCCGAGT & $655-675$ & \multirow{2}{*}{1.68} \\
\hline IL 18R1 (R) & & GCAGAGCAGTTGAGCCTTACG & $842-862$ & \\
\hline ITGAM (F) & NM_001145808.1 & CTCTCTCCCAGGCTCCAGT & $1827-1845$ & \multirow{2}{*}{1.79} \\
\hline ITGAM (R) & & CATTCCTTGCCACTTCССТ & $1986-2004$ & \\
\hline ITGA2B (F) & NM_000419.4 & AAGATTGTGCTGCTGGACG & $2421-2439$ & \multirow{2}{*}{1.81} \\
\hline ITGA2B (R) & & GAAGGTGGATGCTGAGGTGA & $2612-2631$ & \\
\hline ITGB3 (F) & NM_000212.2 & AGTAACCTGCGGATTGGCTT & $537-556$ & \multirow{2}{*}{1.81} \\
\hline ITGB3 (R) & & CACACTCTGCTTCTTCACTTCC & $713-734$ & \\
\hline LTA $(F)$ & NM_001159740.2 & GCTGCTGCTGGTTCTGCT & $282-299$ & \multirow{2}{*}{1.65} \\
\hline LTA (R) & & GTTCTGCTTGCTGGGGTCT & $420-438$ & \\
\hline MGST1 (F) & NM_145792.2 & CAGGTAATGGATGATGAAGTA & $81-101$ & \multirow{2}{*}{1.79} \\
\hline MGST1 (R) & & GCCAAATGCTACACAGTCTTCT & $206-227$ & \\
\hline MMP9 (F) & NM_004994.2 & ACCCTTGTGCTCTTCCCTG & $98-116$ & \multirow{2}{*}{1.70} \\
\hline$M M P 9(R)$ & & CGACTCTCCACGCATCTCTG & $192-211$ & \\
\hline$N P C 1(F)$ & NM_000271.4 & CAGCCACATAACCAGAGCGT & $3778-3797$ & \multirow{2}{*}{1.78} \\
\hline$N P C 1(R)$ & & AGCCAACACCACAATCCCT & $3898-3916$ & \\
\hline
\end{tabular}




\begin{tabular}{|c|c|c|c|c|}
\hline \multicolumn{5}{|l|}{ Table I/ continued } \\
\hline NPC2 $(F)$ & NM_006432.3 & TCCCATTCCTGAGCCTGAT & $362-380$ & \multirow{2}{*}{1.82} \\
\hline$N P C 2(R)$ & & GTTGCCACTCCACCACCA & $478-495$ & \\
\hline$N R 1 H 2(F)$ & NM_007121.5 & GCCATCATCTCAGTCCAGG & $1104-1122$ & \multirow{2}{*}{1.79} \\
\hline$N R 1 H 2(R)$ & & ACTCTGTCTCGTGGTTGTAGC & $1237-1257$ & \\
\hline$N R 1 H 3(F)$ & NM_005693.3 & GCCTTGCTCATTGCTATCAG & $1319-1338$ & \multirow{2}{*}{1.86} \\
\hline$N R 1 H 3(R)$ & & GTGGGAACATCAGTCGGTCA & $1447-1466$ & \\
\hline OLR1 (F) & NM_002543.3 & TTGCCTGGGATTAGTAGTGACC & $249-270$ & \multirow{2}{*}{1.77} \\
\hline OLR1 (R) & & CTTCTTCTGCTTGTTGCCG & $376-394$ & \\
\hline PCTP (F) & NM_021213.3 & GGTGAAGCAATACAAGCAGAG & $578-598$ & \multirow{2}{*}{2.18} \\
\hline$P C T P(R)$ & & TAATGAGCCAGGACGGAAT & $672-690$ & \\
\hline PLA2G7 (F) & NM_005084.3 & GGCATTGACCTGGCATCTC & $759-777$ & \multirow{2}{*}{1.86} \\
\hline PLA2G7 (R) & & TGTGTCTCCTCCTCTTGTTTCAG & 894-916 & \\
\hline PRKCQ (F) & NM_006257.4 & ACTGCCACCTTCTTCCCAC & $587-605$ & \multirow{2}{*}{1.55} \\
\hline PRKCQ (R) & & CTTGAGTCCTTGCCGTGC & $866-883$ & \\
\hline SLC7A11 (F) & NM_014331.3 & GTCCGCAAGCACACTCCT & $1358-1375$ & \multirow{2}{*}{1.97} \\
\hline SLC7A11 (R) & & ATGACGAAGCCAATCCCTG & $1629-1647$ & \\
\hline$S L P I(F)$ & NM_003064.3 & CCTTCCTGGTGCTGCTTG & $44-61$ & \multirow{2}{*}{2.28} \\
\hline$S L P I(R)$ & & GACAACATCTCTTCTTCCCTGG & $193-214$ & \\
\hline SOD2 (F) & NM_000636.3 & CACCACAGCAAGCACCAC & $309-326$ & \multirow{2}{*}{1.80} \\
\hline SOD2 (R) & & GTTCTCCACCACCGTTAGG & $480-498$ & \\
\hline SREBF1 $(F)$ & NM_001005291.2 & CCTCAGATACCACCAGCGTC & 1828-1847 & \multirow{2}{*}{1.68} \\
\hline SREBF1 (R) & & TTGCGATGCCTCCAGAAGT & $2026-2044$ & \\
\hline S100A8 (F) & NM_001319196.1 & ATGCCGTCTACAGGGATGA & $267-285$ & \multirow{2}{*}{1.74} \\
\hline S100A8 (R) & & ACGCCCATCTTTATCACCAG & $407-426$ & \\
\hline S100A9 (F) & NM_002965.3 & GACCATCATCAACACCTTCCAC & $82-103$ & \multirow{2}{*}{1.68} \\
\hline S100A9 (R) & & TAGCCTCGCCATCAGCAT & $284-301$ & \\
\hline S100A12 (F) & NM_005621.1 & ATTAGGCTGGGAAGATGACAA & $55-75$ & \multirow{2}{*}{1.90} \\
\hline S100A12 (R) & & GTGGGTGTGGTAATGGGCA & $320-338$ & \\
\hline TLR5 (F) & NM_003268.5 & GACCCTCTGCCCCTAGAATAA & $581-601$ & \multirow{2}{*}{1.75} \\
\hline$T L R 5(R)$ & & GCCATCAAAGGAGCAGGAA & $707-725$ & \\
\hline$T L R 8(F)$ & NM_016610.3 & GGAACATCAGCAAGACCCATC & $115-135$ & \multirow{2}{*}{1.80} \\
\hline$T L R 8(R)$ & & CGCATAACTCACAGGAACCAGA & $279-300$ & \\
\hline TNFRSF1A (F) & NM_001065.3 & GCTCCTTCACCGCTTCAGA & $563-581$ & \multirow{2}{*}{1.74} \\
\hline TNFRSF1A (R) & & GGTCCCATTGAGGCAGAGG & $744-762$ & \\
\hline TNFRSF1B (F) & NM_001066.2 & AACACACGCAGCCAACTCC & $763-781$ & \multirow{2}{*}{1.77} \\
\hline TNFRSF1B (R) & & GTCACACCCACAATCAGTCCA & $875-895$ & \\
\hline VEGFA $(F)$ & NM_001025366.2 & GAGGGCAGAATCATCACGAA & $1136-1155$ & \multirow{2}{*}{1.79} \\
\hline VEGFA (R) & & CATCAGGGGCACACAGGA & $1264-1281$ & \\
\hline \multicolumn{5}{|c|}{ HDL-related genes*) } \\
\hline$L D L R(F)$ & NM_000527.4 & GAGGTGGCCAGCAATAGAA & $1490-1508$ & \multirow{2}{*}{2.00} \\
\hline$L D L R(R)$ & & GATGACGGTGTCATAGGAAGAG & $1572-1593$ & \\
\hline LIPC $(F)$ & NM_000236.2 & СТTCAАСТССТСССТGССТСТ & 285-305 & \multirow{2}{*}{1.87} \\
\hline LIPC (R) & & TGGTGTAGTGGTCGTGGGC & $433-451$ & \\
\hline
\end{tabular}

*) the data for other twenty HDL-related and three housekeeping genes were published (14). 
analysis of primer efficiencies was done with the REST software (16), and the relative expression of all target genes normalized by the geometric mean of three reference genes was used in the correlation analysis. We did linear regression and Pearson's correlation $r$ tests between biochemical variables with transcript levels to determine the statistical significance and correlation. We used the Benjamini-Hochberg correction for multiple comparisons with the false discovery rate (FDR) value as 0.15 within the recommended range of 0.10 - 0.20 (17). $P$-values $<0.05$ were considered statistically significant.

\section{Results}

Expression of genes related to HDL metabolism

PBMC expression level of 22 genes included in HDL cluster was measured by RT-PCR and significant associations of transcripts with plasma lipids are given in Table III. Significant associations existed between the transcripts of eleven genes and HDL-C. HDL-C level positively correlated with mRNA content of APOA1 gene, while negatively with transcripts of cholesterol transporters (ABCA1 and SCARB1), LDL receptor $(L D L R)$, lecithin:cholesterol acyltransferase $(L C A T)$, zinc finger DHHC-type containing 8 (ZDHHC8), bone morphogenetic protein 1 (BMP1), high density lipoprotein binding protein (HDLBP), cubilin $(C U B N)$, protein kinase CAMP-activated catalytic subunit beta and gamma (PRKACB, PRKACG). Total cholesterol level also negatively correlated with transcript levels of the majority of the above-mentioned genes with the exception of $L D L R$ and $P R K A C B$ genes. However, LDL-C level negatively correlated with transcripts of CUBN and HDLBP genes. Importantly, plasma TG level did not correlate with the transcript levels of HDL cluster genes.

Table III Bivariate correlations between transcript level of HDL cluster and atherogene cluster genes and lipids. Pearson correlation coefficient and $p$-values in brackets are included only for significant associations corrected for multiple comparisons by the Benjamini-Hochberg procedure. The functionality of protein products derived from STRING database and literature data is included also.

\begin{tabular}{|c|c|c|c|c|}
\hline Gene & HDL-C & Chol & LDL-C & Protein functionality \\
\hline \multicolumn{5}{|c|}{ HDL cluster } \\
\hline$A B C A 1$ & $-0.3759(0.0200)$ & $-0.3906(0.0150)$ & & $\begin{array}{l}\text { cAMP-dependent and sulfonylurea-sensitive anion } \\
\text { transporter. Key gatekeeper influencing intracellular } \\
\text { cholesterol transport; Belongs to the ABC transporter } \\
\text { superfamily. Activated by phosphorylation ATP-bind- } \\
\text { ing cassette transporter A1 (ABCA1) interacts with } \\
\text { ApoA-I, allowing their lipidation and formation of } \\
\text { pre-B HDL particles that leads to the efflux of free } \\
\text { cholesterol and phospholipid from different cell types } \\
(18,19) \text {. }\end{array}$ \\
\hline APOA1 & $0.3579(0.0270)$ & & & $\begin{array}{l}\text { Participates in the reverse transport of cholesterol } \\
\text { from tissues to the liver for excretion by promoting } \\
\text { cholesterol efflux from tissues and by acting as a } \\
\text { cofactor for the lecithin cholesterol acyltransferase } \\
\text { (LCAT). ApoA-I, a mature protein product of } \\
\text { APOA1, as a part of pre-B HDL particles binds cellu- } \\
\text { lar cholesterol and phospholipids that leads to lipid } \\
\text { efflux from the cell }(20,21) \text {. }\end{array}$ \\
\hline BMP1 & $-0.4853(0.0020)$ & $-0.3654(0.0240)$ & & $\begin{array}{l}\text { Cleaves the C-terminal propeptides of procollagen I, II } \\
\text { and III. Induces cartilage and bone formation. May } \\
\text { participate in dorsoventral patterning during early } \\
\text { development by cleaving chordin (CHRD). Responsible } \\
\text { for the proteolytic activation of lysyl oxidase LOX. } \\
\text { Being the metalloproteinase, BMP-1 leaves human } \\
249 \text {-aa proapolipoprotein ApoA-I to generate the } \\
\text { mature } 243 \text { aa polypeptide and leads to its activation } \\
\text { for lipid binding and efflux from the cell as nascent } \\
\text { HDL (22). This conversion is going in the presence of } \\
\text { the cell surface lipid transporter ABCA1. }\end{array}$ \\
\hline CUBN & $-0.4282(0.0070)$ & $-0.4281(0.0070)$ & $-0.4360(0.0060)$ & $\begin{array}{l}\text { Cotransporter which plays a role in lipoprotein, vitamin } \\
\text { and iron metabolism, by facilitating their uptake. } \\
\text { Binds to ALB, MB, Kappa and lambda-light chains, TF, } \\
\text { hemoglobin, GC, SCGB1A1, APOA1, high-density } \\
\text { lipoprotein, and the GIF-cobalamin complex. The } \\
\text { binding of all ligands requires calcium. The multili- } \\
\text { gand endocytic receptor Cubilin (CUBN), together } \\
\text { with its coreceptor, LDL-related protein-2 (LRP2), can } \\
\text { bind to apolipoprotein ApoA-l, a major component of } \\
\text { HDL, and promote their endocytosis, which leads to } \\
\text { their reabsorption into the plasma from glomerular fil- } \\
\text { trate, ensuring the maintenance of their plasma levels } \\
(23-25) \text {. }\end{array}$ \\
\hline
\end{tabular}




\begin{tabular}{|c|c|c|c|c|}
\hline \multicolumn{5}{|c|}{ Table III continued } \\
\hline HDLBP & $-0.3540(0.0320)$ & $-0.4733(0.0030)$ & $-0.4321(0.0080)$ & $\begin{array}{l}\text { Vigilin; Appears to play a role in cell sterol metabolism. It } \\
\text { may function to protect cells from over-accumulation of } \\
\text { cholesterol. The actual function of vigilin (HDLBP) is } \\
\text { unknown. Vigilin induced by cholesterol and sterol hor- } \\
\text { mones and found human atherosclerotic lesions. The high } \\
\text { constitutive levels of vigilin mRNA in fibroblasts of patients } \\
\text { with familial HDL deficiency may reflect impaired choles- } \\
\text { terol transport in these cells }(26,27) \text {. }\end{array}$ \\
\hline LCAT & $-0.3536(0.0290)$ & $-0.3249(0.0470)$ & & $\begin{array}{l}\text { Synthesized mainly in the liver and secreted into plasma } \\
\text { where it converts cholesterol and phosphatidylcholines } \\
\text { (lecithins) to cholesteryl esters and lysophosphatidyl- } \\
\text { cholines on the surface of high and low-density lipopro- } \\
\text { teins (HDLs and LDLs). The cholesterol ester is then trans- } \\
\text { ported back to the liver. Lecithin: cholesterol } \\
\text { acyltransferase (LCAT) promotes the conversion of the dis- } \\
\text { coidal (nascent) HDL to spherical HDL }(28,29) \text {. LCAT } \\
\text { reacts with the unesterified cholesterol in HDL, transferring } \\
\text { the } 2 \text {-acyl group of lecithin or phosphatidylethanolamine to } \\
\text { the free hydroxyl residue of cholesterol to generate } \\
\text { cholesteryl esters, which are retained in the core of HDL. }\end{array}$ \\
\hline$L D L R$ & $-0.3784(0.0230)$ & & & $\begin{array}{l}\text { Binds LDL, the major cholesterol-carrying lipoprotein of } \\
\text { plasma, and transports it into cells by endocytosis. In order } \\
\text { to be internalized, the receptor-ligand complexes must first } \\
\text { cluster into clathrin-coated pits. The low-density lipopro- } \\
\text { tein receptor (LDLR) binds cholesterol-rich LDL particles } \\
\text { and promote their clearance from the circulation into the } \\
\text { cells where in the lysosomes cholesterol of LDL particles } \\
\text { becomes available again by hydrolysis of the cholesteryl } \\
\text { esters (30). }\end{array}$ \\
\hline PRKACB & $-0.3162(0.0530)$ & $-0.3637(0.0270)$ & & $\begin{array}{l}\text { Mediates cAMP-dependent signalling triggered by recep- } \\
\text { tor binding to GPCRs. PKA activation regulates diverse } \\
\text { cellular processes such as cell proliferation, the cell cycle, } \\
\text { differentiation and regulation of microtubule dynamics, } \\
\text { chromatin condensation and decondensation, nuclear } \\
\text { envelope disassembly and reassembly, as well as regula- } \\
\text { tion of intracellular transport mechanisms and ion flux. } \\
\text { Being the catalytic subunit of cAMP-dependent protein } \\
\text { kinase (PKA), the protein product of PRKACB is involved } \\
\text { in PKA-mediated ABCA1 phosphorylation, allowing lipi- } \\
\text { dation of ApoA-I which leads to lipid efflux from the cell } \\
\text { as nascent HDL }(18,31,32) \text {. }\end{array}$ \\
\hline PRKACG & $-0.3569(0.0300)$ & $-0.4656(0.0030)$ & & $\begin{array}{l}\text { Phosphorylates a large number of substrates in the cyto- } \\
\text { plasm and the nucleus; Belongs to the protein kinase } \\
\text { superfamily. Being the catalytic subunit of cAMP-depen- } \\
\text { dent protein kinase (PKA), the protein product of } \\
\text { PRKACG is involved in PKA-mediated ABCA1 phospho- } \\
\text { rylation, allowing lipidation of ApoA-I which leads to lipid } \\
\text { efflux from the cell as nascent HDL }(18,31,32) \text {. }\end{array}$ \\
\hline SCARB 1 & $-0.4439(0.0050)$ & $-0.3655(0.0240)$ & & $\begin{array}{l}\text { Receptor for different ligands such as phospholipids, } \\
\text { cholesterol ester, lipoproteins, phosphatidylserine and } \\
\text { apoptotic cells. Receptor for HDL, mediating selective } \\
\text { uptake of cholesteryl ether and HDL-dependent choles- } \\
\text { terol efflux. Also facilitates the flux of free and esterified } \\
\text { cholesterol between the cell surface and apoB-contain- } \\
\text { ing lipoproteins and modified lipoproteins, although less } \\
\text { efficiently than HDL. Scavenger receptor class B type I } \\
\text { (SCARB 1) interacts with spherical and discoidal HDL par- } \\
\text { ticles and remodels the HDL (28). }\end{array}$ \\
\hline $\mathrm{ZDHHC} 8$ & $-0.4923(0.0020)$ & & & $\begin{array}{l}\text { Palmitoyltransferase involved in glutamatergic transmis- } \\
\text { sion. Mediates palmitoylation of ABCA1. Palmitoylation } \\
\text { of ABCA1 may regulate its function as a transporter and } \\
\text { therefore lipid efflux from the cell (33). }\end{array}$ \\
\hline
\end{tabular}




\begin{tabular}{|c|c|c|}
\hline \multicolumn{3}{|c|}{ Table III continued } \\
\hline \multicolumn{3}{|c|}{ atherogene cluster } \\
\hline CSF1R & $-0.3512(0.0330)$ & $\begin{array}{l}\text { Tyrosine-protein kinase that acts as cell-surface receptor for } \\
\text { CSF1 and IL34 and plays an essential role in the regulation } \\
\text { of survival, proliferation and differentiation of hematopoietic } \\
\text { precursor cells, especially mononuclear phagocytes, such as } \\
\text { macrophages and monocytes. Promotes the release of } \\
\text { proinflammatory chemokines in response to IL34 and } \\
\text { CSF1, and thereby plays an important role in innate immu- } \\
\text { nity and in inflammatory processes. }\end{array}$ \\
\hline IL18R1 & $-0.3898(0.0170)$ & $\begin{array}{l}\text { Within the IL18 receptor complex, responsible for the bind- } \\
\text { ing of the proinflammatory cytokine IL18, but not IL1A nor } \\
\text { IL1B (Probable). Contributes to IL18-induced cytokine pro- } \\
\text { duction, either independently of SLC12A3, or as a complex } \\
\text { with SLC12A3. }\end{array}$ \\
\hline ITGB3 & $-0.5355(0.0010)$ & $\begin{array}{l}\text { Integrin alpha-V/beta-3 (ITGAV:ITGB3) is a receptor for } \\
\text { cytotactin, fibronectin, laminin, matrix metalloproteinase-2, } \\
\text { osteopontin, osteomodulin, prothrombin, thrombospondin, } \\
\text { vitronectin and von Willebrand factor. Integrin alpha- } \\
\text { Ilb/beta-3 (ITGA2B:ITGB3) is a receptor for fibronectin, fib- } \\
\text { rinogen, plasminogen, prothrombin, thrombospondin and } \\
\text { vitronectin. Integrins alpha-IIb/beta-3 and alpha-V/beta-3 } \\
\text { recognize the sequence R-G-D in a wide array of ligands. } \\
\text { Integrin alpha- IIb/beta-3 recognizes the sequence H-H-L- } \\
\text { G-G-G-A-K-Q-A-G-D-V in fibrinogen gamma chain. }\end{array}$ \\
\hline ITGAM & $-0.4039(0.0130)$ & $\begin{array}{l}\text { Integrin ITGAM/ITGB2 is implicated in various adhesive } \\
\text { interactions of monocytes, macrophages and granulocytes } \\
\text { as well as in mediating the uptake of complement-coated } \\
\text { particles. It is identical with CR-3, the receptor for the iC } 3 \mathrm{~b} \\
\text { fragment of the third complement component. It probably } \\
\text { recognizes the R-G-D peptide in C } 3 \mathrm{~b} \text {. Integrin } \\
\text { ITGAM/ITGB2 is also a receptor for fibrinogen, factor } X \text { and } \\
\text { ICAM1. }\end{array}$ \\
\hline SREBF1 & $-0.3666(0.0260)$ & $\begin{array}{l}\text { Transcriptional activator required for lipid homeostasis. } \\
\text { Regulates transcription of the LDL receptor gene as well as } \\
\text { the fatty acid and to a lesser degree the cholesterol synthesis } \\
\text { pathway (By similarity). Binds to the sterol regulatory ele- } \\
\text { ment } 1 \text { (SRE-1) (5'-ATCACCCCAC-3'). }\end{array}$ \\
\hline TLR5 & $-0.3649(0.0240)$ & $\begin{array}{l}\text { Participates in the innate immune response to microbial } \\
\text { agents. Mediates detection of bacterial flagellins. Acts via } \\
\text { MYD88 and TRAF6, leading to NF-kappa-B activation, } \\
\text { cytokine secretion and the inflammatory response. }\end{array}$ \\
\hline TLR8 & $-0.5129(0.0010)$ & $\begin{array}{l}\text { Key component of innate and adaptive immunity. TLRs con- } \\
\text { trol host immune response against pathogens through } \\
\text { recognition of molecular patterns specific to microorgan- } \\
\text { isms. Acts via MYD88 and TRAF6, leading to NF-kappa-B } \\
\text { activation, cytokine secretion and the inflammatory }\end{array}$ \\
\hline TNFRSF1A & $-0.3718(0.0220)$ & $\begin{array}{l}\text { Receptor for TNFSF2/TNF-alpha and homotrimeric } \\
\text { TNFSF1/lymphotoxin-alpha. The adapter molecule FADD } \\
\text { recruits caspase- } 8 \text { to the activated receptor. The resulting } \\
\text { death-inducing signalling complex (DISC) performs cas- } \\
\text { pase- } 8 \text { proteolytic activation which initiates the subsequent } \\
\text { cascade of caspases (aspartate- specific cysteine proteases) } \\
\text { mediating apoptosis. }\end{array}$ \\
\hline
\end{tabular}




\begin{tabular}{|l|l|l|l|l|}
\hline \multicolumn{2}{|l|}{ Table III continued } & & $\begin{array}{l}\text { Receptor with high affinity for TNFSF2/TNF-alpha and } \\
\text { approximately 5-fold lower affinity for homotrimeric } \\
\text { TNFSF1/lymphotoxin-alpha. The TRAF1/TRAF2 complex } \\
\text { recruits the apoptotic suppressors BIRC2 and BIRC3 to } \\
\text { TNFRSF1B/TNFR2. This receptor mediates most of the } \\
\text { metabolic effects of TNF-alpha. Isoform 2 blocks TNF- } \\
\text { alpha-induced apoptosis, which suggests that it regulates } \\
\text { TNF-alpha function by antagonizing its biological activity. }\end{array}$ \\
\hline CSF2RB & -0.4677 (0.0030) & & $\begin{array}{l}\text { High affinity receptor for interleukin-3, interleukin-5 and } \\
\text { granulocyte-macrophage colony-stimulating factor. }\end{array}$ \\
\hline PRKCQ & $-0.4080(0.0120)$ & & $\begin{array}{l}\text { Calcium-independent, phospholipid- and diacylglycerol } \\
\text { (DAG)-dependent serine/threonine-protein kinase that } \\
\text { mediates non- redundant functions in T-cell receptor (TCR) } \\
\text { signalling, including T-cells activation, proliferation, differ- } \\
\text { entiation and survival, by mediating activation of multiple } \\
\text { transcription factors such as NF-kappa-B, JUN, NFATC1 } \\
\text { and NFATC2. }\end{array}$ \\
\hline
\end{tabular}

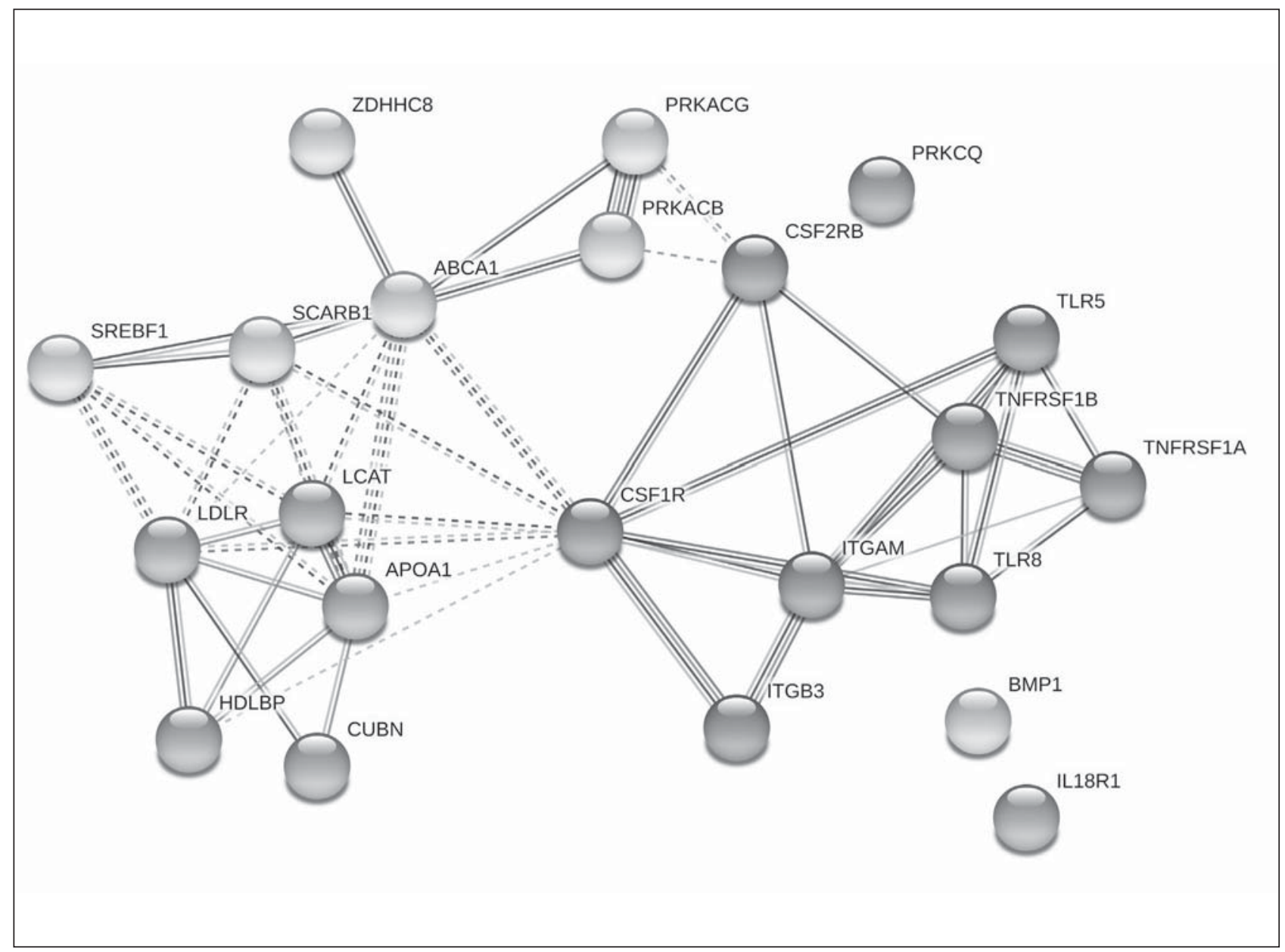

Figure 1 STRING analysis of protein-protein interactions between proteins coded by genes from HDL and atherogene clusters. Six kmeans clusters are chosen. Number of nodes: 22; number of edges: 50; average node degree: 4.55; avg. local clustering coefficient: 0.647; expected number of edges: 11; PPI enrichment p-value: $<1.0 \mathrm{e}-16$. 


\section{Expression of atherogenesis-prone genes}

HDL-C negatively correlated with the transcript levels of eleven genes among 41 genes included in atherogene cluster (Table III). These genes code integrin subunit beta 3 (ITGB3), Toll-like receptors 5 and 8 (TLR5 and TLR8), TNF receptor superfamily member $1 \mathrm{~A}$ and $1 \mathrm{~B}$ (TNFRSF1A and TNFRSF1B); interleukin 18 receptor 1 (IL18R1), integrin subunit alpha M (ITGAM); colony-stimulating factor 2 receptor beta common subunit (CSF2RB), colony-stimulating factor 1 receptor (CSF1R), sterol regulatory element-binding transcription factor 1 (SREBF 1), and protein kinase $\mathrm{C}$ theta (PRKCQ).

Functional interactions between protein products of genes included in two clusters

The functional interactions between protein products of 22 genes, with PBMC expression level significantly associated with HDL-C level, were revealed by STRING database (15). The functional properties of proteins are included in Table III. Twentytwo nodes are involved in 50 interactions (Figure 1), which significantly exceeds eleven random interactions. Generally, nine from eleven genes from HDL cluster belong to Reactome Plasma lipoprotein assembly, remodelling, and clearance pathway (HSA174824), based on minimal FDR value mentioned in STRING database. However, nine from eleven genes from the atherogene cluster belong to the Immune System pathway (HSA-168256). Two clusters intersect only at two nodes, namely CSFR 1 (six edges) and CSF2RB (two edges) (Figure 1).

\section{Discussion}

The associations between plasma lipids and PBMC expression of 63 genes included in two clusters were studied for a cohort of 38 middle-aged male patients without coronary atherosclerosis with widely varied HDL-C. For the first time, the significant positive correlation between HDL-C and APOA 1 expression and negative correlations of HDL-C and transcripts of ten HDL-related genes and eleven atherogenesis-prone genes even at the absence of morphologically evident coronary stenosis were revealed. The protein products efficiently interacted within both clusters, but only two-node intersections existed between them.

Monocytes are the main source of proinflammatory mediators at atherogenesis (34) that constitute one-fifth of the mononuclear cell fraction. PBMC expression of 41 genes included in the atherogene cluster was measured in the present study for 38 patients with a widely varied $\mathrm{HDL}-\mathrm{C}$ level. $\mathrm{HDL}-\mathrm{C}$ level negatively correlated with transcript content for eleven genes. The protein products of the some genes are of primary importance in inflammation and immune response, namely colony-stimulating factor receptors, TNF receptor superfamily members $1 \mathrm{~A}$ and 1B, TLR5 and TLR8 receptors that induce the proinflammatory cytokine, and IL18 cytokine receptor that participates in innate immunity response and is a critical molecule in atherosclerosis-connected inflammation (35). Molecular mechanisms of the inhibition of expression by HDL remain unknown. HDL inhibits endothelial and monocyte expression of tissue factor (TF), the major coagulation factor, by inhibiting the activation of p38 MAPK (mitogen-activated protein kinase) and the repression of the PI3K (phosphoinositide 3-kinase) pathway responsible for TF expression (36). It should be noted that the negative correlation between HDL-C and ITGB3 and ITGAM gene transcripts observed here coincides with the inhibition of integrin and endothelial cell adhesion molecules by HDL $(6,37)$. Overall, our data on the negative correlation between HDL-C and pro-inflammatory gene transcripts suggest the decay of atherogenesis-related inflammation with the increase of HDL-C. Besides, PBMC expression of atherogenesis-sensitive genes is suggested to be controlled only by HDL-C level, due to the lack of any association with LDL-C and plasma TG. Both conclusions are the major novelties of our study.

The limitation of our study is the expression profiling of only two gene clusters; the genome-wide transcriptome analysis may reveal some additional genes involved in atherogenesis-related pathways. Also, a detailed study of mRNA and protein expression and enzyme and receptor activities would confirm the metabolic traits suggested to be influenced by the genes in two clusters. However, both mRNA and protein expression of HDLBP/vigilin is upregulated similarly by intracellular cholesterol loading (27).

The positive correlation between HDL-C and APOA 1 transcript existed among 22 HDL-related genes, while ten gene transcripts (ABCA1, BMP1, CUBN, HDLBP, LCAT, LDLR, PRKACB, PRKACG, $S C A R B 1$ and ZDHHC8) correlated negatively; they included six genes mentioned earlier (14). Four gene transcripts (CUBN, HDLBP, PRKACB, and PRKACG) negatively correlated with HDL-C in the present study. The significant decrease of HDLBP which expression is upregulated by intracellular cholesterol loading (27), thus confirms our earlier suggestion (14) on the decreased level of cholesterol in PBMC at hyperalphalipoproteinemia. Additionally, the decrease of the CUBN transcript, which codes the receptor for apoAI and HDL (25), may result in an increase of HDL level. A decrease in the content of LCAT and SCARB 1 transcripts may be suggested to result in the diminished flow of cholesteryl ester to the liver, thus contributing to hyperalphalipoproteinemia (14).

Functional relations between protein products of genes in two clusters include only two crossing genes. The existence of only two nodes may correspond to 
the limited number of synchronous changes in node activities in both clusters and the possibility of discordant changes of cluster functionality. Functional isolation of two clusters may underlie the possibility of non-coincident changes between the loss of HDL function and the gain of dysfunction (12). Multiple pleiotropic effects, namely anti-inflammatory activity, vasodilatory function, antiapoptotic activity, antioxidative activity and cholesterol efflux capacity (12), characterize HDL functions. It may be speculated further that therapy targeting these two nodes, for instance by drugs andĐor microRNA, may influence both HDL functionality and atherogenesis. Interestingly, one of two nodes, namely CSF2RB mRNA, possesses the greatest pleiotropy across six cardiometabolic traits (38).

\section{Conclusion}

Coordinate regulation of cholesterol influx and efflux in PBMC in atherosclerosis-free subjects with widely varied HDL-C level is suggested. The decreased synthesis and transport of cholesteryl ester to the liver may contribute to hyperalphalipoproteinemia. HDL-C increase is associated with the decrease of expression of innate immunity and inflammation genes. Visualization of twenty-two responder genes is suggested to be useful in the validation of HDL functionality and atherogenesis even at the absence of morphologically evident coronary stenosis.

Acknowledgements. The reported study was funded by the Russian Foundation for Basic Research according to the research project No. 17-04-00217.

\section{Conflict of interest statement} interest.

The authors declare that they have no conflict of

9. Teslovich TM, Musunuru K, Smith AV, Edmondson AC, Stylianou IM, Koseki $M$ et al. Biological, clinical and population relevance of 95 loci for blood lipids. Nature 2010; 466: 707-13.

10. Kosmas CE, Christodoulidis G, Cheng JW, Vittorio TJ, Lerakis S. High-density lipoprotein functionality in coronary artery disease. Am J Med Sci 2014; 347: 504-8.

11. Kosmas CE, Martinez I, Sourlas A, Bouza KV, Campos FN, Torres $V$ et al. High-density lipoprotein (HDL) functionality and its relevance to atherosclerotic cardiovascular disease. Drugs Context 2018; 7: 212525.

12. Rosenson RS, Brewer HB Jr, Ansell BJ, Barter P, Chapman MJ, Heinecke JW et al. Dysfunctional HDL and atherosclerotic cardiovascular disease. Nat Rev Cardiol 2016; 13: 48-60.

13. Dmitrieva VG, Savushkin EV, Zuikova EB, Nosova EV, Litvinov DY, Dergunov AD et al. Key Human Blood Cells Genes Involved in Atherogenesis and Metabolism of High Density Lipoproteins. Molecular Genetics, Microbiology and Virology 2018; 33: 84-90.

14. Dergunov AD, Litvinov DY, Bazaeva EV, Dmitrieva VG, Nosova EV, Rozhkova AV et al. Relation of High-Density Lipoprotein Charge Heterogeneity, Cholesterol Efflux Capacity, and the Expression of High-Density Lipoprotein-Related Genes in Mononuclear Cells to the HDLCholesterol Level. Lipids 2018; 53: 979-91.

15. Szklarczyk D, Gable AL, Lyon D, Junge A, Wyder S, Huerta-Cepas J et al. STRING v11: protein-protein association networks with increased coverage, supporting functional discovery in genome-wide experimental datasets. Nucleic Acids Res 2019; 47: D607-D613.

16. Pfaffl MW, Horgan GW, Dempfle L. Relative expression software tool (REST) for group-wise comparison and staprotect from atherosclerosis? J Lipid Res 2010; 51: 2058-73. 
tistical analysis of relative expression results in real-time PCR. Nucleic Acids Res 2002; 30: e36.

17. McDonald JH (2015) Multiple comparisons. Handbook of Biological Statistics. http://www. biostathandbook. com/multiplecomparisons [3rd ed.], 254-260. Baltimore, Maryland, Sparky House Publishing.

18. Krimbou L, Marcil M, Genest J. New insights into the biogenesis of human high-density lipoproteins. Curr Opin Lipidol 2006; 17: 258-67.

19. Favari E, Lee M, Calabresi L, Franceschini G, Zimetti F, Bernini $F$ et al. Depletion of pre-beta-high density lipoprotein by human chymase impairs ATP-binding cassette transporter $\mathrm{A} 1$ - but not scavenger receptor class $B$ type I-mediated lipid efflux to high density lipoprotein. J Biol Chem 2004; 279: 9930-6.

20. Nakamura Y, Kotite L, Gan Y, Spencer TA, Fielding CJ, Fielding PE. Molecular mechanism of reverse cholesterol transport: reaction of pre-beta-migrating high-density lipoprotein with plasma lecithin/cholesterol acyltransferase. Biochemistry 2004; 43: 14811-20.

21. Fielding $P E$, Kawano $M$, Catapano AL, Zoppo $A$, Marcovina S, Fielding CJ. Unique epitope of apolipoprotein A-I expressed in pre-beta-1 high-density lipoprotein and its role in the catalyzed efflux of cellular cholesterol. Biochemistry 1994; 33: 6981-5.

22. Chau P, Fielding PE, Fielding CJ. Bone morphogenetic protein-1 (BMP-1) cleaves human proapolipoprotein A1 and regulates its activation for lipid binding. Biochemistry 2007; 46: 8445-50.

23. Aseem O, Smith BT, Cooley MA, Wilkerson BA, Argraves $K M$, Remaley AT et al. Cubilin maintains blood levels of HDL and albumin. J Am Soc Nephrol 2014; 25: 1028 36.

24. Hammad SM, Barth JL, Knaak C, Argraves WS. Megalin acts in concert with cubilin to mediate endocytosis of high density lipoproteins. J Biol Chem 2000; 275: 12003-8.

25. Kozyraki R, Fyfe J, Kristiansen M, Gerdes C, Jacobsen C, Cui $S$ et al. The intrinsic factor-vitamin B12 receptor, cubilin, is a high-affinity apolipoprotein A-I receptor facilitating endocytosis of high-density lipoprotein. Nat Med 1999; 5: 656-61.

26. Marcil M, Yu L, Krimbou L, Boucher B, Oram JF, Cohn JS et al. Cellular cholesterol transport and efflux in fibroblasts are abnormal in subjects with familial HDL deficiency. Arterioscler Thromb Vasc Biol 1999; 19: 159-69.
27. Chiu DS, Oram JF, LeBoeuf RC, Alpers CE, O'Brien KD. High-density lipoprotein-binding protein (HBP)/vigilin is expressed in human atherosclerotic lesions and colocalizes with apolipoprotein E. Arterioscler Thromb Vasc Biol 1997; 17: 2350-8.

28. Zannis VI, Chroni A, Krieger M. Role of apoA-I, ABCA1, LCAT, and SR-BI in the biogenesis of HDL. J Mol Med (Berl) 2006; 84: 276-94.

29. Asztalos BF, Schaefer EJ, Horvath KV, Yamashita S, Miller $M$, Franceschini $G$ et al. Role of LCAT in HDL remodeling: investigation of LCAT deficiency states. J Lipid Res 2007; 48: 592-9.

30. Gent J, Braakman I. Low-density lipoprotein receptor structure and folding. Cell Mol Life Sci 2004; 61: 246170.

31. Haidar B, Denis M, Krimbou L, Marcil M, Genest J, Jr. CAMP induces ABCA1 phosphorylation activity and promotes cholesterol efflux from fibroblasts. J Lipid Res 2002; 43: 2087-94.

32. Haidar B, Denis M, Marcil M, Krimbou L, Genest J, Jr. Apolipoprotein A-I activates cellular cAMP signaling through the ABCA1 transporter. J Biol Chem 2004; 279: 9963-9.

33. Singaraja RR, Kang MH, Vaid K, Sanders SS, Vilas GL, Arstikaitis P et al. Palmitoylation of ATP-binding cassette transporter $\mathrm{A} 1$ is essential for its trafficking and function. Circ Res 2009; 105: 138-47.

34. Ganjali S, Gotto AM, Jr., Ruscica M, Atkin SL, Butler AE, Banach $M$ et al. Monocyte-to-HDL-cholesterol ratio as a prognostic marker in cardiovascular diseases. J Cell Physiol 2018; 233: 9237-46.

35. Boraschi D, Dinarello CA. IL-18 in autoimmunity: review. Eur Cytokine Netw 2006; 17: 224-52.

36. Ossoli A, Remaley AT, Vaisman B, Calabresi L, Gomaraschi M. Plasma-derived and synthetic high-density lipoprotein inhibit tissue factor in endothelial cells and monocytes. Biochem J 2016; 473: 211-9.

37. Murphy AJ, Woollard KJ, Hoang A, Mukhamedova N, Stirzaker RA, McCormick SP et al. High-density lipoprotein reduces the human monocyte inflammatory response. Arterioscler Thromb Vasc Biol 2008; 28: 2071-7.

38. McManus DD, Rong J, Huan T, Lacey S, Tanriverdi K, Munson PJ et al. Messenger RNA and MicroRNA transcriptomic signatures of cardiometabolic risk factors. BMC Genomics 2017; 18: 139. 